\title{
BESKRYWING VAN AFRIKA IN 1641
}

Agter op 'n oorspronklike kaart tan Afrika in Latyn opgestel deur Hondius*

Die orde vereis dat ons sal praat oor Afrika, die moeder van wonderlike dinge, wat gelei het tot die spreekwoord: Afrika bring altyd iets nuuts te voorskyn. In die Arabiese taal word dit genoem Iphrichia, van die woord faraca, wat dieselfde beteken as verdeel in Latyn; sommige dink dat dit so genoem is omdat dit van Europa afgeskei is deur die Middellandse See en van Asië deur die Nylrivier. (N.B. teenswoordig word die naam Afrika afgelei van Afer, die naam van een van die seuns van Hercules, wat volgens die legende ook in Noord-Afrika avonture beleef het, en sy seun agtergelaat het om hom met sy laer effe Wes van dic latere Carthago te vestig. Die gewone klassieke naam vir Noord-Afrika was egter Libië, sodat ons eie nasie eintlik die eerste Afrikaners of „PanAfricans" was, vanaf die $18 \mathrm{e}$ eeu altans. L. J. du P.).

Maar ander lei hierdie naam af van Ifricus, 'n koning van Arabia felix, wat volgens die verhaal eerste hierdie land begin bewoon het. Hy sou dan, na die oorwinning op hom deur die koning van Assirië en sy gevolglike verdrywing uit sy koninkryk, met sy hele leër oor die Nyl getrek het en sy magte na die Weste gelei het en eers tot rus gekom het, toe hy die landstreek in die buurt van Carthago bereik het. En hiervandaan kom dit dan dat die Arabiere die gebied en streek van Carthago en daardie westelike deel as Afrika beskou.

Sommige glo dat die Afrikane afkomstig is van die Palesty. ners wat deur die Assiriërs verjaag is, toe in Afrika aangekom het en, volgens die verhaal, hulle daar gevestig het vanweë die vrugbaarheid van die bodem. Ander dink dat hulle afkomstig is van die Sabeërs, 'n volk, soos gesê is, van Arabia felix. Party meen dat hulle afstammelinge is van sekere inwoners van KleinAsië; hulle skryf dat dié nasie dan, toe 'n oorlog teen hulle deur 'n sekere groep aan die gang gesit is, daarvandaan na Griekeland weggevlug het, wat op daardie tyd nog geen inwoners gehad het nie. Mar toe die vyand hulle nog verder agtervolg het na Griekeland, sou hulle noodgedwonge die Peloponnesiese See oorgevaar het en hul woonplek gevestig het in Afrika. Maar dit alles moet verstaan word van die oorsprong slegs van hulle wat effe bruin van kleur is, dit is van die Numidiërs en Berbers. Want al

\footnotetext{
* Die oorspronklike kaart word bewaar in dic Potchefstroomse Munisipale
} Museum. 
die negers is afkomstig van Kus, die seun van Gam, wat die seun was van Noag. Maar watter soort verskil daar ook mag wees tussen die negers en die bruin-mense, het hulle tog almal dieselfde oeroorsprong. Want laasgenoemdes kom van die Palestyners, maar die Palestyners van Misraim, die seun van Gam; terwyl eergenoemdes dit wil hê dat hulle afkomstig is van die Sabeërs, maar dit is bekend dat Saba geboortig is van Ram, die seun van Gam.

Dit is kleiner as Asië. Sy lengte word bereken vanaf die Straat van Hercules (Gibraltar) tot by die Kaap van Goeie Hoop, op $5200 \mathrm{myl}$; en die breedte tussen die twee voorgebergtes, $\mathrm{nl}$. dié van Hesperië, bekend as Kaap Verde, en Aromata wat geleë is by die ingang van die Arabiese golf, bekend as Kaap Guardafuy, 5050 myl. Die geheel is ' $n$ soort skiereiland wat aan die Noorde hegrens word deur die Middellandse See, aan die Weste deur die Atlantiese- en Ethiopiese Oseaan, aan die Suide deur die Indiese Oseaan, aan die Ooste deur die Rooi See, waar dit deur 'n landengte aan Asië verbind word, waarvan die maat 25 myl is. Daar bestaan 'n meningsverskil onder die aardrykskundiges of die $\mathrm{Nyl}$ Asië van Afrika skei, wat die meeste wel bevestig. Maar in hierdie saak is dit verkieslik om die mening te volg van die vernaamste aardrykskundiges. Afrika word volgens die mening van Pomponius Mela van Asië geskei deur die Nylrivier en die Suidelike lyn getrek vanaf die afvloeiing daarvan tot by die Ethiopiese See. Maar Ptolomaeus het voorkeur gegee aan die opvatting dat Asië van Afrika afgeskei word deur die Arabiese Golf en die Suid-Noord-lyn wat daarvandaan getrek word na die Middellandse See deur die landengte wat Egipte verbind aan Arabië en Judea. Want Ptolomaeus beskou dit ook nie as gepas nie dat Egipte uiteengeskeur sou word en 'n deel daarvan aan Afrika, maar 'n ander deel aan Asië toegereken sou word, wat die geval sou wees, as die Nyl tot grens gemaak sou word tussen Asië en Afrika. (N.B. die Arabiese Golf is later weer genoem die Rooi See - L. J. du P.). Ortelius egter skryf op sy algemene kaart van Afrika soos volg: „Daar moet op gelet word dat hulle wat die hele Afrika insluit tussen die Middellandse See, die Atlantiese en Ethiopiese Oseane en die Nylrivier, Egipte en Ethiopië by Asië reken, terwyl ons meen dat dié landstreke by Afrika getel moet word." Want inderdaad die ware Ethiopië hevat die ryk van Priester Johannes, soos hulle hom noem, en dit word teenswoordig deur almal by Afrika gereken. Ons oordeel dus dat dit eerder saam met Ptolomaeus deur die Middellandse See en die Oseaan as deur die Nylrivier omgrens behoort te word.

Die meer Suidelike deel van Afrika of die verste Suidelike deel was in die ou tyd heeltemal onbekend tot in die jaar van Christus 1497, toe Vasco da Gama onder beskerming van die 
koning van Lusitanië (Portugal - L. J. du P.) Afrika omseil het, en nadat hy die mees Suidelike kaap van Afrika, wat die Kaap ran Goeie Hoop genoem word, verby gevaar het, Calentta bereik het. Die grootste deel daarvan is onbewerk en of met onvrugbare sand oordek òf woestyngebied vanweë die hemelstreek en die aardrykskundige ligging, ö anders is dit onveilig vanweë talryke skadelike diersoorte. Oor die geheel is dit verlate eerder as bevolk. Tog is sekere dele daarvan buitengewoon vrugbaar. Carthago het dit voorheen beroemd gemaak deur sy stryd met die Romeinse Ryk, asook die Christelike kerke wat talryk was onder Augustinus en ander uitnemende Leermeesters.

Die gebiede en volke waarin dit voorheen verdeel was, is Egipte, Cyrenaica, die kleiner of eintlik so genoemde Afrika, die Troglodiete, Garamante, Numidië, Mauritania, Gaetulia, die binnelandse Libië, die Trogloditiese Arabië en Ethiopië. Watter volke dit oudtyds bewoon het, blyk uit die reeds aangehaalde name van gebiede en volkstamme. Maar die eerste vreemde intrekkers was die Fenisiese nedersetters en ander Asiate. Later was dit onderhorig aan die Romeine, daarna aan die Griekse (Bisantynse I. J. du P.) keisers en later aan die Vandale, Saracene en Arabiere. Vou hou Turkye 'n deel, 'n ander deel die sogenoemde Serifus, terwyl ander konings nog 'n deel het en eindelik word 'n deel beheers deur dic koning van die Spanjes. Maar die Ethiopiërs het van hulle eie land nie weggetrek en ook nie ander nedersetters daarin ontvang nie. Die oorsaak hiervan is die verwyderde ligging van die gebied en die uitgestrekte vlaktes van die tussenliggende woestyne.

Teenswoordig word dit hoofsaaklik verdeel in sewe dele of gebiede, met die volgende name: Egipte, Berberland, Biledulgerid, die Sahara-woestyn, Negerland, die binnelandse Ethiopië, ook genoem die Hoërgeleë Ryk van die Abessiniërs, en die Buite- of Laergeleë Ethiopï,, wat vyf gebiede omvat: Congo, Monomotapa, Zanzibar en Ajan (Monomotapa omvat min of meer die huidige Rhodesië, Betsjoeanaland en Transvaal - L. J. du P.).

Egipte word ingesluit tussen die monde van die $\mathrm{Nyl}$ waarvan die verste Oos lê, die Pelusiese, by Damiata, en aan die Weste-kant die Canopiese, by Alexandria en Pharus. Die hoofstad is nou Cairo, in die spreektaal Alcair, vir die Chaldeërs Alchabyr, 'n stad van verbasende grootte, 'n baie beroemde handelstad. Naby is Materea, 'n tuin beplant met balsembosse, 'n plant wat voorheen slegs in die land Judea voorgekom het, en teenswoordig nêrens anders as op hierdie plek gekweek word nie. Hier is die piramides te sien, naamlik drie klipmassas wat onder die wonders gereken word. Die konings van Egipte het gesorg dat hulle oor die koninklike 
graftes opgerig word, hetsy tot 'n ydele vertoning van rykdom of om die volk uit hulle doodsheid op te wek. Die grootste van hulle het trappe wat aan die buitekant uitstaan. Daar is 250 trappe, waarvan elkeen 'n hoogte van vyf voet het. Elke sykant se oppervlakte-maat is 324 tree. $\mathrm{Op}$ die top van die piramide is daar ' $\mathrm{n}$ plat vlak wat 50 mense kan bevat. 'n Boogskutter wat daarop staan, hoe bedrewe of sterk ook al, sal nooit 'n pyl so ver uit skiet dat dit anderkant die voetstuk van die piramide sou val nie. En daaruit kan afgelei word hoe geweldig groot hierdie bouwerk is. Die tweede in roem is Alexandria. Daarna Raschit, wat die Europeërs Rosetta noem; Damiata, oudtyds Pelusium, beroemd as die geboorteplek van Ptolomaeus, die Aardrykskundige, in verband met wie aan ons Haarlemmers die eer toekom van sy gevangeneming in die verlede. Die stad is sterk en ryk, met 'n gerieflike hawe wat druk besoek word deur skepe en is geleë aan die Pelusiese mond van die Nyl.

Berberland strek van Egipte tot by die Straat van Cadiz (Gibraltar); dit is verdeel in ' $n$ provinsie en vyf koninkryke. Die provinsie is dié van Barca en die koninkryke die Tunetaanse, Tremiseense, Fessaanse, Marokkaanse en Darensiese. Die Tunetaanse koninkryk beslaan byna die hele ou Klein-Afrika. Die hoofstad is Tunis, 'n opvallende ou en taamlik ruime stad wat ontstaan het uit die puinhope van Carthago. Die tweede is Nieu-Tripoli, wat beskryf word as die Berberse om dit te onderskei van die Siriese Tripoli; ook Bona, oudtyds Hippo, bekend weens die episko. paat van die kerkvader Augustinus. In die binneland lê Constantina, gekenmerk deur oorblyfsels van Romeinse oudhede. Die hoofstad van die Tremiseense koninkryk is Tremisen, 'n stad geteister en beskadig deur hewige oorloë. Op die kus daarvan lê Algiers, 'n taamlik befaamde handelstad, maar berug weens die seerowery van die Turke en volgeprop met Christelike slawe. Die stad self is versterk met mure, forte en grofgeskut tot so 'n mate dat dit as oninneembaar beskou word. Na die kant van die Atlantiese See lê die Fessaanse en Marokkaanse koninkryke, waarvan die hoofstad $F e z$ is, die vernaamste stad van die hele Berberland. Maar Tanger, Seuta en Arzilla is groot stede langs die Seestraat, onderhorig aan die Spanjaarde. Die Marokkaanse hoofstad is Maroc, voorheen baie groot en beroemd, met 'n naam onder die grootste wêreldstede.

Die Darensiese koninkryk was vroeër die Mauritaniese Caesarea. Die hoofstad is Dara. Mililla is aan die Middellandse See onderhorig aan Spanje.

Biledulgerid strek op 'n groot afstand van die Egiptiese grense agter die genoemde gebiede uit tot aan die Atlantiese Oseaan. Daarin is die woestyne: Lempta, Hair, Zuenziga, Zanhaga, volgens die name van die onderskeie dorpe. Die koninkryk is 
Terga, Berdoa en Gaoga.

Libie of die Sahara, wat woestyn beteken, sluit aan by hierdie gebied Suidwaarts, en dit lê in die lengte van die koninkryk Gaoga tot by die koninkryk Gualata.

Die negers (of Nigeriërs? - L. J. du P.) woon in 'n groot gebied aan altwee walle van die Niger-rivier. In die lengte strek dit van die Nyl en die eiland Meroë tot by die mond van die Niger en die Oseaan. Daarin lê die volgende koninkryke, genoem na die (onderskeie) stede: Gualata, Hoden, Genocha, Senega, Tonbuti, Melli, Bitonin, Guinea, Temian, Dauma, Cano, Cassena, Benin, Zanfara, Guangara, Borno, Nubia, Biafra, Medra. (Hieronder kan verskeie bekende Wes-Afrikaanse name van ons tyd herken word L. J. du P.).

Oor die binnelandse Ethiopië regeer die koning van die Abessiniërs, wat genoem word Johannes die Priester of die Prysens. waardige, in die omgangstaal Prete Gianni, onder die invloed van 'n groot maar wydverspreide vergissing, aangesien hy vroeër in die Asiatiese koninkryk Tenduc geregeer het. (In Engels word gepraat van „Prester John” - L. J. du P.). Dit word verdeel in baie koninkryke en provinsies, met die volgende name: Dafila, Barnagasso, Dangali, Dobas, Trigemahon, Ambiancantiva, Vangue, Bagamidri, Beleguanze, Angote, Balei, Fatigar, Olabi, Baru, Gemen, Fugni, Tirvae, Esabela, Malemba.

Daar is weinig stede in die hele ryk: grotendeels word in statte gewoon, in struise gemaak van klei en strooi. Die koning self, wat volgens berigte blank is, woon onder tente waarvan 6000 hom volg. Amara is die sterkste fort, verborge op die berg Amara ('n regte Masoes! - L. J. du P.), waar die koningseuns onder sterk beskerming opgevoed word, totdat na die vader se dood die erfgenaam te voorskyn gebring word.

Die res van Afrika word genoem die verdere of laer Ethiopië en word omspoel deur die Oseaan ten Ooste, Suide en Weste. Van die gebiede waarin dit verdeel word, is die eerste die Congo, vir ander Manicongo, wat sy naam kry van die stad Congo (geskryf word Congi, maar Manicongo - L. J. du P.). Die inwoners is Christene. Die grond self is ryklik besproei met rivierwaters. Die residensie is die gemeenskap van San Salvador, voorheen Banza. Die tweede is Monomotapa, met vrugbare grond en lieflike voorkoms; daar is gouddraende riviere en bosse vol olifante. Die hoofstad van die koninkryk en koninklike setel is Monomotapa, by die rivier van die Heilige Gees. Hiervandaan na die Suide op 'n afstand van omtrent vyftig myl is daar 'n pragtige gebou, ruim en oud.... (hier breek die beskrywing af - blykbaar by Zimbabwe! P.U. vir C.H.O.

L. J. du Plessis 